\title{
Effect of hyperbaric oxygen therapy on the intestinal ischemia reperfusion injury ${ }^{1}$
}

\author{
Efeito da oxigenoterapia hiperbárica na lesão por isquemia reperfusão intestinal
}

\author{
Rosemary Aparecida Furlan Daniel ${ }^{\mathrm{I}}$, Vinícius Kannen Cardoso ${ }^{\mathrm{II}}$, Emanuel Góis Jr ${ }^{\mathrm{III}}$, Rogério Serafim Parra ${ }^{\mathrm{IV}}$, Sérgio Britto \\ Garciav , José Joaquim Ribeiro da Rocha $^{\mathrm{VI}}$, Omar Féres ${ }^{\mathrm{VII}}$
}

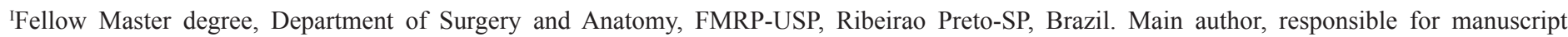
preparation.

IBiomedical, Fellow Master degree, Department of Forensic Medicine and Pathology, Experimental Pathology Section of Cancer Biology, FMRPUSP, Ribeirao Preto-SP, Brazil. Involved with technical procedures.

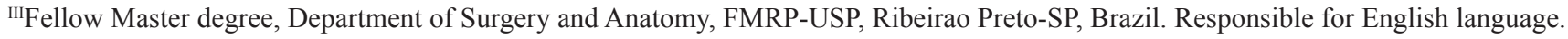

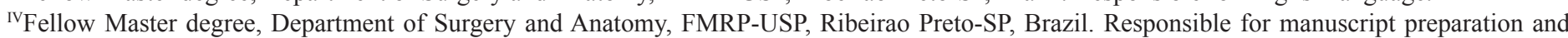
critical revision.

${ }^{v} \mathrm{PhD}$, Full Professor and Head of the Department of Forensic Medicine and Pathology, Experimental Pathology Section of Cancer Biology, FMRPUSP, Ribeirao Preto-SP, Brazil. Responsible for intellectual and scientific content of the study.

${ }^{v} \mathrm{PhD}$, Full Professor and Head of Division of Coloproctology, Department of Surgery and Anatomy, FMRP-USP, Ribeirao Preto-SP, Brazil. Responsible for intellectual and scientific content of the study, critical revision.

${ }^{\mathrm{VII}} \mathrm{PhD}$, Associate Professor, Department of Surgery and Anatomy, FMRP-USP, Ribeirao Preto-SP, Brazil. Responsible for intellectual and scientific content of the study, critical revision.

\begin{abstract}
PURPOSE: Adequate tissue oxygenation is essential for healing. Hyperbaric oxygen therapy (HBOT) has potential clinical applications to treat ischemic pathologies, however the exact nature of any protective effects are unclear at present. We therefore investigated the potential role of HBOT in modulating the ischemia/reperfusion (I/R) injury response in intestinal model of I/R injury.

METHODS: Male Wistar rats were subjected to surgery for the induction of intestinal ischemia followed by reperfusion. HBOT was provided before and/or after intestinal ischemia. Cell viability in the intestinal tissue was assessed using the MTT assay and by measuring serum malondealdehyde (MDA). Microvascular density and apoptosis were evaluated by immunohistochemistry.

RESULTS: The results indicate that HBOT treatment pre- and post-ischemia reduces lesion size to the intestinal tissue. This treatment increases cell viability and reduces the activation of caspase-3, which is associated with increased number of tissue CD34 cells and enhanced VEGF expression.
\end{abstract}

CONCLUSION: The hyperbaric oxygen therapy can limit tissue damage due to ischemia/reperfusion injury, by inducing reparative signaling pathways.

Keywords: Reperfusion Injury. Hyperbaric Oxygenation. Rats.

\section{RESUMO}

OBJETIVO: Oxigenação tissular adequada é essencial para cicatrização. Oxigenoterapia hiperbárica (HBOT) tem aplicação clínica para tratar lesões isquêmicas, entretanto a natureza exata dos mecanismos envolvidos permanece incerta. Procuramos investigar o papel potencial da HBOT na modulação da resposta a uma lesão por isquemia reperfusão (I/R) intestinal em modelo de lesão de I/R.

MÉTODOS: Ratos machos Wistar foram submetidos à cirurgia para a indução da isquemia intestinal seguida de reperfusão. HBOT foi fornecido antes e / ou após a isquemia intestinal. A viabilidade das células no tecido intestinal foi avaliada através do ensaio de MTT e pela medição malondealdeido (MDA) no plasma. Densidade microvascular e apoptose foram avaliados por imuno-histoquímica.

RESULTADOS: Os resultados indicam que o tratamento HBOT pré e pós-isquemia reduz o tamanho da lesão ao tecido intestinal. Este tratamento aumenta a viabilidade celular e reduz a ativação da caspase-3, que está associada com aumento do número de células CD 34 no tecido e da expressão da VEGF.

CONCLUSÃO: A oxigenoterapia hiperbárica pode limitar os danos do tecido devido à lesão por isquemia/reperfusão, induzindo às vias de sinalização reparadora.

Descritores: Traumatismo por Reperfusão. Oxigenação Hiperbárica. Ratos. 


\section{Introduction}

The relationship between mesenteric ischemia and the action of free radicals during the reperfusion period is well established, with tissue damage largely occurring due to reperfusion injury rather than the initial ischemic insult. Hyperbaric oxygen therapy (HBOT) has been employed in various clinical situations, including wounds, carbon monoxide poisoning, necrotizing soft tissue infection, and osteoradionecrosis. However, HBOT has not been systematically used in organ transplantation, despite the frequency of ischemia and reperfusion experienced by patients during this procedure. Current knowledge indicates that HBOT increases the $\mathrm{O}_{2}$ concentration in tissues with impaired blood supply ${ }^{1}$ and diminishes the inflammatory process by interfering with the production and the activity of cytokines. Additionally, HBOT stimulates wound healing, angiogenesis and osteogenesis, thereby elevating antioxidant enzyme levels and relieving tissue hypoxia ${ }^{2}$.

Vascular endothelial growth factor (VEGF) is a key signaling protein that induces neovascularization during tissue repair. Oxygen tension is a key regulator of VEGF expression both in vitro and in vivo, with hypoxia a potent inducer of VEGF. More recently, hyberbaric oxygen has also been demonstrated to induce VEGF formation ${ }^{3}$. The expression of VEGF is related to the expression of the $\mathrm{CD} 34+$ antigen, which induces the expression of endothelial progenitor cells (EPCs) of both hematopoietic and vascular origin ${ }^{4}$. CD34+ cells are detected in newly formed blood vessels under pathological conditions and are associated with the accelerated restoration of blood flow ${ }^{5}$. Because of the association of VEGF and CD34+ expression with neovascularization and the restoration of blood flow, they are appropriate markers for tracking the role of HBOT in improving the outcomes associated with ischemia and reperfusion. The aim of this work is to explore this process in a rat model of bowel surgery.

\section{Methods}

This work was approved by the Institutional Research Ethics Committee. Thirty Wistar rats weighing 300-400g were provided by the animal housing facilities of the institution and were maintained in metal cages at a temperature of $24^{\circ} \mathrm{C}$. The animals were treated according to the instructions of the Committee with regard to laboratory handling and care.

\section{Experimental design}

The rats were randomly distributed into five groups of six animals each. The first group was designated the Control group. Animals of the second group (I-R) were subjected to surgeryinduced ischemia/reperfusion; the rats in the third group (I-R/ HBOT) received the surgery followed by HBOT; the fourth group (HBOT/I-R/HBOT) was treated with HBOT before and after the surgical procedure, and the fifth group (HBOT/I-R) was treated with HBOT prior to surgery but not afterwards.

\section{Surgical procedure}

The animals were anesthetized by intraperitoneal injection of $1.0 \mathrm{~g}$ Thiopentax (sodium thiopental - Cristália; dosage $=50 \mathrm{mg} / \mathrm{kg}$ ). Intestinal ischemia was achieved by occluding the superior mesenteric artery for sixty minutes using a microvascular clamp ${ }^{6}$. The occurrence of ischemia was recognized by the presence of pale intestinal loops that lacked a pulse (Figure 1). The abdominal cavity was temporarily closed by means of a continuous suture. After sixty minutes of ischemia, the cavity was reopened, the microvascular clamp was removed, and reperfusion was initiated (3h). Reperfusion was identified by the return of a pulse and by the restoration of the pink coloration of the intestine. All of the animals were euthanized after three hours of reperfusion. Animals in the control group were anesthetized, and their abdominal cavities were opened, but they were not subjected to ischemia/reperfusion.

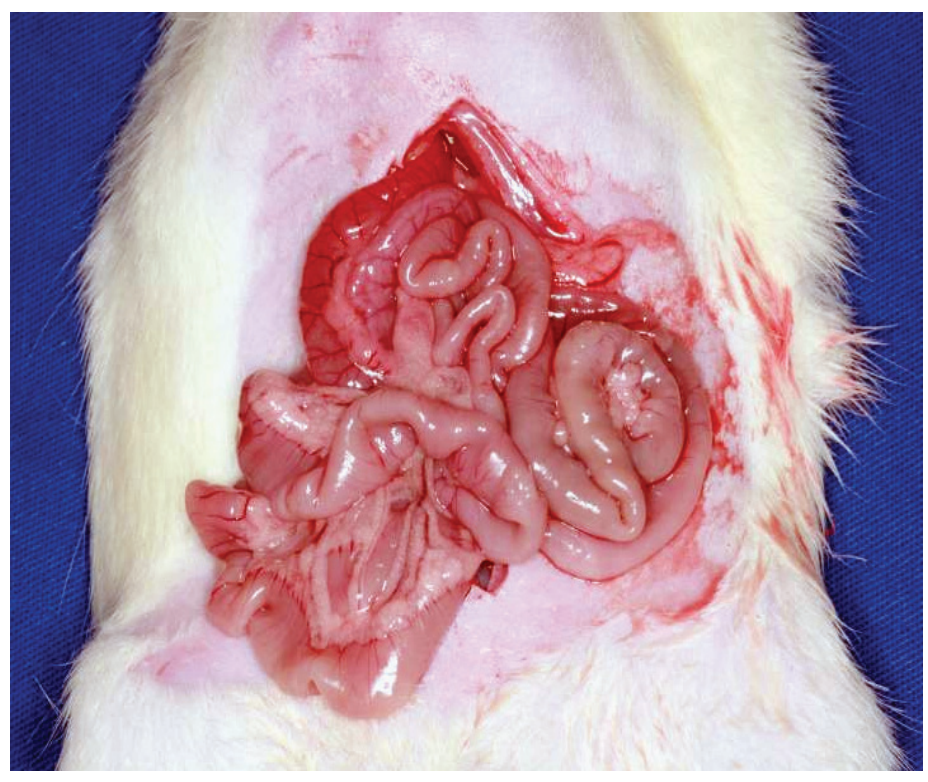

FIGURE 1 - Pale intestinal loops following the placement of the microvascular clamp - Beginning of ischemia 


\section{HBOT treatment}

The animals were placed in an experimental hyperbaric chamber for the application of HBOT. Each HBOT session lasted two hours, i.e., fifteen minutes of pressurization of up to 2 ATA and the maintenance of this pressure for ninety minutes, followed by fifteen minutes of depressurization.

\section{Sample collection and euthanasia}

At the end of the experiment, the abdominal cavity was reopened and $20 \mathrm{~cm}$ of the intestine was removed. The first $10-\mathrm{cm}$ section was used for the methyl thiazolyl blue (MTT) assay, while the remaining $10-\mathrm{cm}$ section was fixed in $10 \%$ formalin solution in preparation for histological and immunohistochemical evaluation. Blood samples were collected using vacuum tubes (Vacutainer) containing EDTA for the determination of malondealdehyde (MDA) plasma levels. Following sample collection, the animals received an extreme dose of anesthetics that culminated in cardiorespiratory arrest.

\section{Biochemical analysis - MTT and MDA}

For MTT analysis, intestinal samples were collected in Eppendorf tubes $(1.5 \mathrm{~mL})$ with $550 \mu \mathrm{L} \mathrm{PBS}$ and $5.5 \mu \mathrm{L}$ MTT $(5 \mathrm{mg} /$ $\mathrm{mL}$, Sigma), which was incubated at $37^{\circ} \mathrm{C}$ for two hours. Next, $400 \mu \mathrm{L}$ of isopropyl acid ( $\mathrm{HCl} 0.004 \mathrm{~N}$ propanol) was added, and the resulting solution was incubated at room temperature for five minutes, followed by homogenization. The analysis was repeated five times for each animal, and the results were obtained using a spectrophotometer (ZEISS, SPEKOL 1,100) at a calibrated wavelength of $570 \mathrm{~nm}$. The results are expressed as absorbance.

MDA levels were determined by means of the TBAR technique (thiobarbituric acid reactive substances). MDA reacts with thiobarbituric acid to give a fluorescent pink chromogen that absorbs at $532 \mathrm{~nm}$ and emits fluorescence at $553 \mathrm{~nm}^{7,8}$.

\section{Histopathological evaluation}

The intestine samples were fixed according to standard procedures $^{8}$.

Mucosal lesions were examined by two independent pathologists and classified according to the method developed by Chiu on the basis of hematoxylin-eosin staining'.

\section{Immunohistochemical analysis}

Immunohistochemical reactions were performed on the histological sections prepared on paraffin by means of an antigen-antibody reaction followed by detection with a marker and observation under a microscope. The slides were treated with the primary antibody cysteine protease protein (CPP)-32-caspase-3, clone JHM62, diluted 1:300 for twelve hours and incubated in a humidified chamber, at which time the antibody reacted with the antigen, forming an immunocomplex. For staining of the VEGF and $\mathrm{CD} 34+$ cells, the following specific antibodies were utilized: VEGF-NCL-L-VEGFR-3 (clone KLT9; 1:200) and CD34+-NCLEND-CD34 (clone QBEnd/10; 1:100).

\section{Statistical analysis}

The data were analyzed using the program GraphPad Prism 5 (Graph Pad Software In., San Diego, California, USA). The Kolmogorov-Smirnov test was applied to verify the normal distribution of the data. In the case of normal distribution, Oneway ANOVA and Tukey post-test were performed. Significance was set at $\mathrm{p}<0.05$.

\section{Results}

The histopathological evaluation and classification of the lesions detected in the experimental groups and the control animals is summarized in Table 1, using the criteria proposed by Chiu. To evaluate the effect of HBOT on intestinal I/R injury and lesion formation, we used the well described rat mesenteric model of $\mathrm{I} / \mathrm{R}$. No lesions were detected in the mucosa of the Control animals, whereas the I-R group presented grade 5 tissue injuries, characterized by the loss of the villi. In the I-R/HBOT group, the lesions were categorized as grades 4 and 5, with epitheliumdenuded villi. For the the HBOT/I-R/HBOT group, grade 2 lesions were observed (i.e., extended sub-epithelial spaces between the villi and visible cell lysis). Grade 3 and 4 lesions were observed in the HBOT/I-R group, with significant epithelial lifting down the sides of the villi. Taken together, HBOT prior to ischemia reperfusion (HBOT/I-R/HBOT and HBOT/I-R groups) limited injury to the intestinal mucosa.

TABLE 1 - Classification of the mucosa lesions detected in the experimental animals according to $\mathrm{Chiu}^{9}$

\begin{tabular}{cccccc}
\hline $\begin{array}{c}\text { Group } \\
\text { Animals }\end{array}$ & $\begin{array}{c}\text { Control } \\
\text { group }\end{array}$ & $\begin{array}{c}\text { I-R } \\
\text { group }\end{array}$ & $\begin{array}{c}\text { HBO/I-R } \\
\text { group }\end{array}$ & $\begin{array}{c}\text { HBO/I-R/HBO } \\
\text { group }\end{array}$ & $\begin{array}{c}\text { I-R/HBO } \\
\text { group }\end{array}$ \\
\hline $\mathbf{1}$ & grade 0 & grade 5 & grade 3 & grade 3 & grade 4 \\
$\mathbf{2}$ & grade 0 & grade 5 & grade 3 & grade 2 & grade 4 \\
$\mathbf{3}$ & grade 0 & grade 5 & grade 3 & grade 2 & grade 4 \\
$\mathbf{4}$ & grade 0 & grade 5 & grade 3 & grade 2 & grade 4 \\
$\mathbf{5}$ & grade 0 & grade 5 & grade 4 & grade 2 & grade 4 \\
$\mathbf{6}$ & grade 0 & grade 5 & grade 3 & grade 2 & grade 5 \\
\hline
\end{tabular}


There was a significant increase in the MTT levels in the groups treated with HBOT (HBOT/I-R, HBOT/I-R/HBOT) (Figure 1), demonstrating increased cell viability in these groups. Additionally, reduced MDA levels were detected in the HBOT/ I-R/HBOT group (Figure 2) compared with the groups without HBOT $(\mathrm{p}<0.05 ; \mathrm{p}<0.01)$.

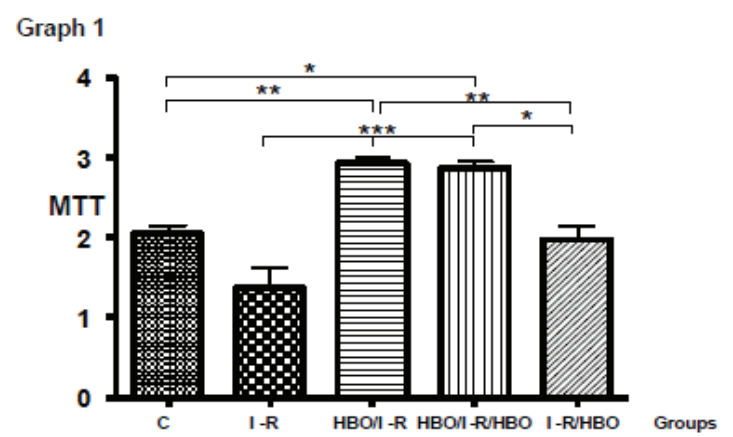

Graph 2

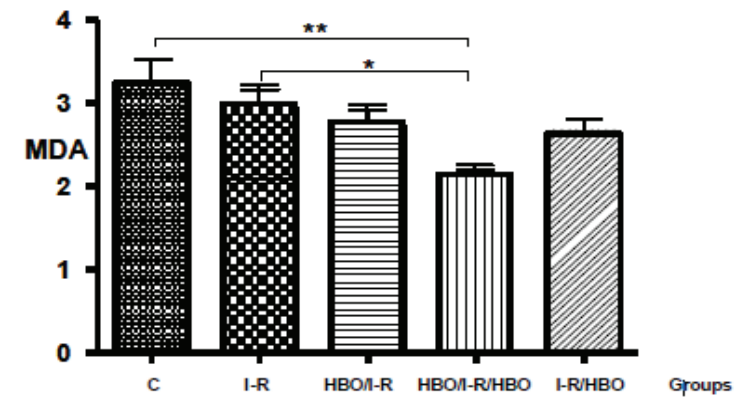

FIGURES 1 and 2 - Analysis of the results from the MTT assays and MDA determinations in the experimental and Control groups. There are significant differences among the groups

Examination of the expression of CD34+ and VEGF levels in the HBOT/I-R/HBOT group compared with the other groups (Control, I-R, HBOT/I-R, I-R/HBOT) $(\mathrm{p}<0.01 ; \mathrm{p}<0.001)$ revealed a significant elevation of both CD34+ and VEGF (Figures 3 and 4). VEGF expression in the HBOT/I-R/HBOT group was significantly elevated compared with the HBOT/I-R $(\mathrm{p}<0.001)$ and I-R/HBOT $(p<0.01)$ groups. The expression of VEGF was similar to that of $\mathrm{CD} 34+(\mathrm{p}<0.01 ; \mathrm{p}<0.001$, respectively) for both I-R and I-R/HBOT groups (Figures 5 and 6 ).

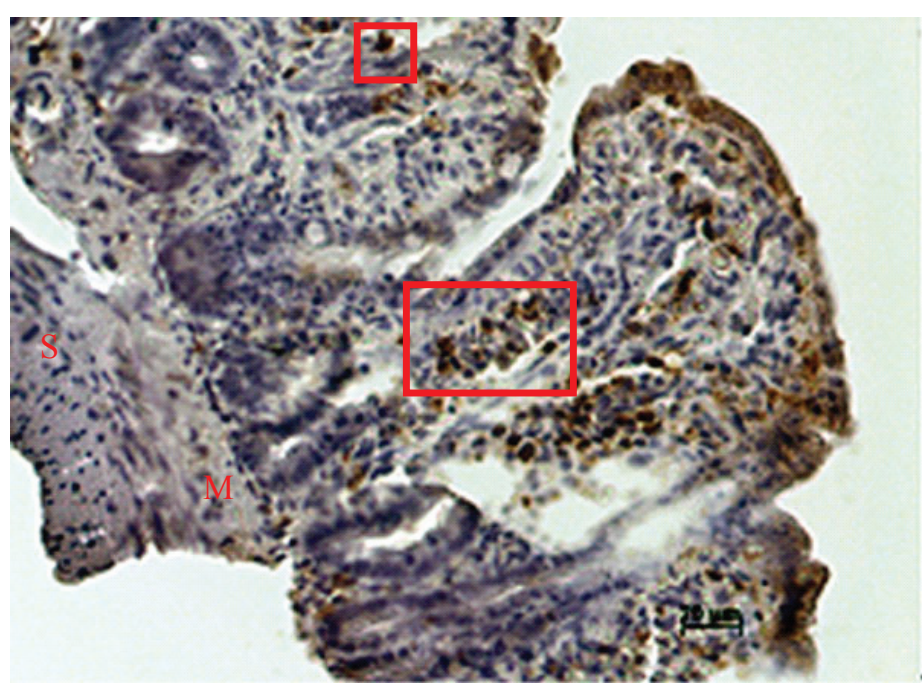

FIGURE 3 - Immunohistochemical analysis of the HBO/I-R/HBO group V- vilosity, M- mucosa, S- serosa, - CD34+ markers

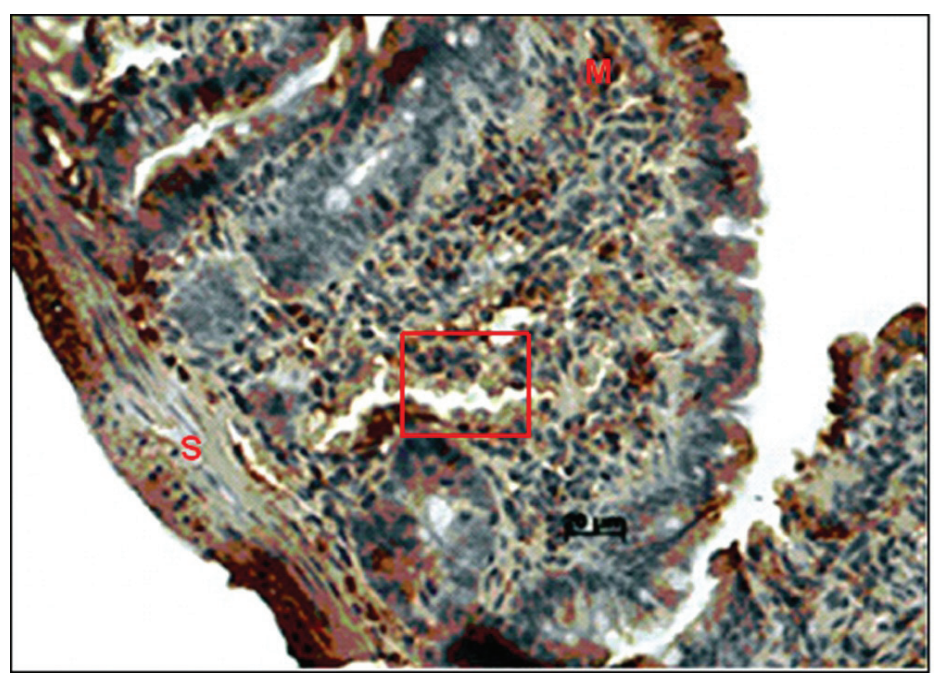

FIGURE 4 - Immunohistochemical analysis of the HBO/I-R/HBO group. M- mucosa, S- serosa, - VEGF markers 
Graph 3

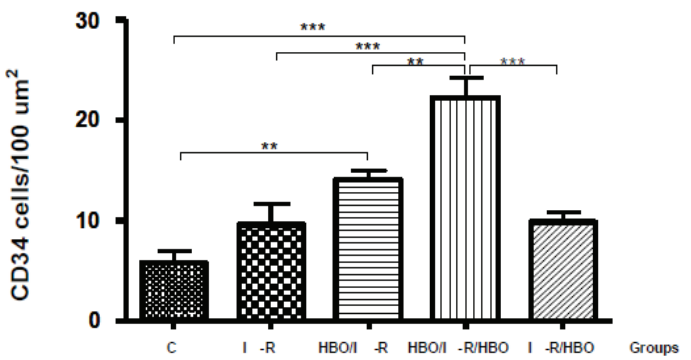

Graph 4

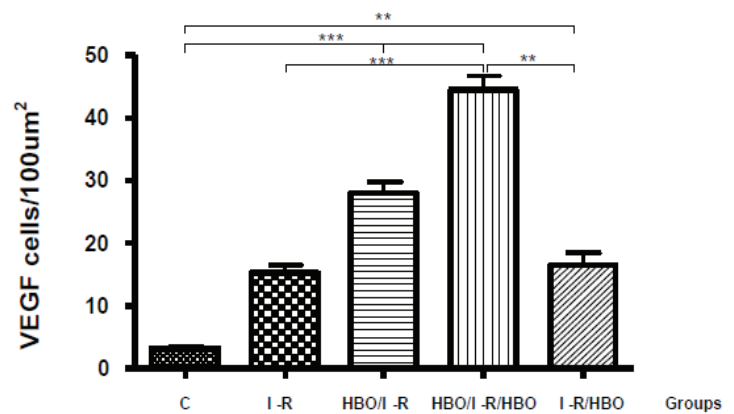

FIGURES 5 and 6 - Results from the CD34+ and VEGF determination in the experimental and Control groups. There are significant differences among the groups.

We also examined cytosolic caspase 3 in the intestinal mucosa (Figure 7). There was a significant decrease in the levels of caspase-3 expression in the HBOT/I-R/HBOT group compared with the groups without HBOT (Figure 8).

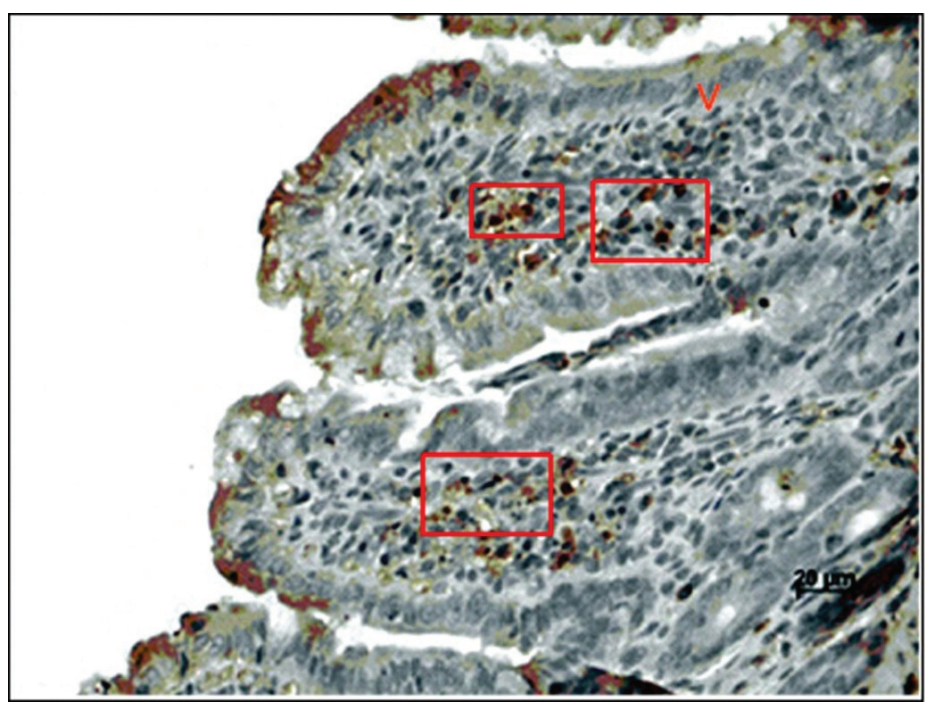

FIGURE 7 - Immunohistochemical aspect of caspase-3 in the HBO/I-R/ HBO group.

V - villosity,- caspase-3 markers

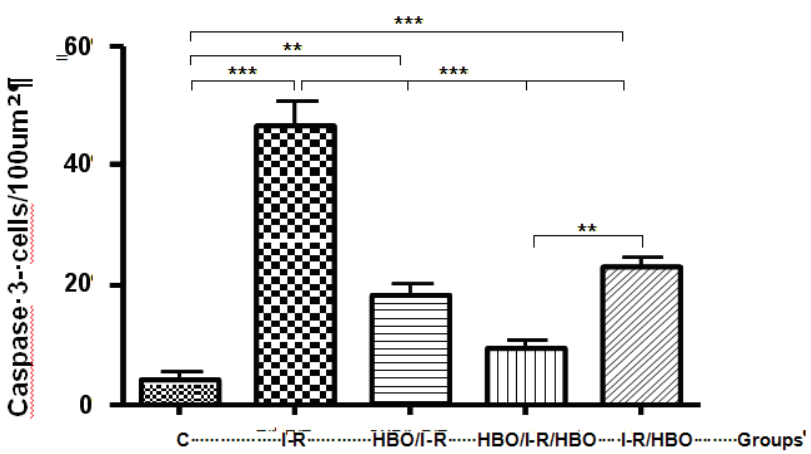

FIGURE 8 - Caspase- 3 expression levels in the experimental and Control groups. The best result was achieved for the HBO/I-R/HBO group, with statistical significance.

\section{Discussion}

HBOT enhances oxygen concentration in tissues stimulating angiogenesis ${ }^{10}$ and led to a reduction in tissue damage. Additionally, a decreased number of inflammatory cells were detected in the ischemic intestinal mucosa, in accordance with recent studies indicating that HBOT therapy may diminish the inflammatory response $\mathrm{e}^{10,11}$. In our experimental model, there was an attenuated inflammatory response due to HBOT treatment and a maintenance of the intestinal mucosa following ischemiareperfusion injury.

In the current study, immunohistochemical analysis revealed that both the HBOT/I-R/HBOT and the HBOT/I-R treatment group led to an increase in VEGF and CD34+ cells. Studies of in vitro ischemia have shown VEGF expression is the key regulator of enhanced vascular and endothelial cell permeability ${ }^{11,12}$ and hypoxia maintains the characteristics of CD34+ cells by decreasing intracellular levels of reactive oxygen species $^{13}$. However, in the case of the HBOT/I-R/HBOT and HBOT/I-R groups, there was a significant rise in the number of tissue CD34+ cells. These findings are in agreement with previous human studies which demonstrated an increase in the population of $\mathrm{CD} 34+$ cells in the peripheral circulation in response to HBOT exposure for two hours ${ }^{14}$. Additionally, HBOT is known to stimulate stem/progenitor cell mobilization from the bone marrow, thereby accelerating the growth of vascular channels and stimulating vasculogenic mediators ${ }^{15}$.

It is likely that the effects of HBOT on intestinal ischemic tissues are similar to its effect on cardiac ischemic tissues. In the latter case, hypoxic-ischemic pre-conditioning induces a significant increase in the level of CD34+ cells in the peripheral blood. This protective effect is facilitated by the mobilization of 
circulating progenitor cells, which improve cardiac contractility and ameliorate the ischemic injury ${ }^{16,17}$. Previous studies have indicated that HBOT exerts multiple actions on a variety of cellular pathways and functions, including apoptotic genes ${ }^{18}$, neuroprotection, decreased mortality and diminished ischemic cellular damage ${ }^{19,10}$. Here, we demonstrate a significant rise in the expression of caspase- 3 in the I-R group, corroborating previous results ${ }^{21}$. HBOT therapy before and after I-R was associated with a significant decrease in the expression of caspase-3, concomitant with decreased cellular damage, as detected in the histological evaluation (grade 2). In accordance with our findings preconditioning with HBOT has previously been shown to increase survival and suppress activity of caspase- 3 and caspase- $9^{22}$. There is a relationship between the effect of HBOT on I-R injury in the bowels and apoptotic injury in the mucosa ${ }^{22}$. Early treatment with HBOT has a beneficial effect on ischemia ${ }^{23}$. These parameters may also be associated with increased VEGF expression. The evidence is clear that VEGF is anti-apoptotic agent and enhanced angiogenesis ${ }^{24}$. HBOT promotes tissue preservation with reduced apoptosis because it diminishes the levels of superoxide and hydrogen peroxide, resulting in a subsequent reduction in the amount of cytochrome $\mathrm{c}$ in the cytosol ${ }^{25}$. Indeed, Nylander et al. ${ }^{26}$ have observed improved mitochondrial function associated with HBOT.

An increase in MTT levels, indicitive of cell health were observed in the HBOT/I-R/ HBOT and HBOT/I-R groups. We speculate that enhanced VEGF expression induced by HBOT may lead to an increase in capillary density or vasodilation, thus promoting tissue oxygenation ${ }^{27}$. This re-establishment of tissue function is further supported by the MDA results, which revealed a low level of lipid peroxidation in the HBOT/I-R/HBOT group, as described previously ${ }^{28,29}$.

HBOT treatment has been shown to attenuate proinflammatory cytokine release in response to potent inflammatory stimulus lipopolysaccharide (LPS) ${ }^{30,31}$. HBOT pre-conditioning is also associated with a decrease in nervous tissue injury, lower mortality, recovery of neurological function, reduced MDA levels, and increased antioxidant activity ${ }^{22,32}$. In this work, we have extended these findings to include a role for HBOT as a protective stimulus that limits tissue damage in response to intestinal ischemia and reperfusion. We suggest further investigation to determine if HBOT can be applied clinically as an adjuvant therapy for tissue damage occurring due to vessel ligation in organ transplantation.

\section{Conclusion}

The hyperbaric oxygen therapy can limit tissue damage due to ischemia/reperfusion injury, by inducing reparative signaling pathways.

\section{References}

1. Fischer BR, Palkovic S, Holling M, Wolfer J, Wassmann H. Rationale of hyperbaric oxygenation in cerebral vascular insult. Curr Vasc Pharmacol. 2010;8:35-43.

2. Al-Waili NS, Butler GJ, Lee BY, Carrey Z, Petrillo R. Possible application of hyperbaric oxygen technology in the management of urogenital and renal diseases. J Med Eng Technol. 2009;33(7):50715.

3. Fok TC, Jan A, Peel SA, Evans AW, Clokie CM, Sándor GK. Hyperbaric oxygen results in increased vascular endothelial growth factor (VEGF) protein expression in rabbit calvarial critical-sized defects. Oral Surg Oral Med Oral Pathol Oral Radiol Endod. 2008;105:417-22.

4. Kajbafzadeh AM, Payabvash S, Salmasi AH, Sadeghi Z, Elmi A, Vejdani K, Tavangar SM, Tajik P, Mahjoub F. Time-dependent neovasculogenesis and regeneration of different bladder wall components in the bladder acellular matrix graft in rats. J Surg Res, 2007;139(2):189-202.

5. Schatteman GC, Hanlon HD, Jiao C, Dodds SG, Christy BA. Bloodderived angioblasts accelerate blood-flow restoration in diabetic mice. J Clin Invest. 2000;106(4):571-8.

6. Paiva LA, Gurgel LA, Camposa AR, Silveira ER, Raoa VS, Attenuation of ischemia/reperfusion-induced intestinal injury by oleo-resin from Copaifera langsdorffii in rats. Life Sci. 2004;75(16):1979-87.

7. Therond P, Bonnefont-Rousselot D, David-Spraul A, Conti M, Legrand A. Biomarkers of oxidative stress: an analytical approach. Curr Opin Clin Nutr Metab Care. 2000;3(5):373-84.

8. Vasconcelos SML, Goulart MOF, Moura JBF, Benfato MS, Kubota LT. Espécies reativas de oxigênio e de nitrogênio, antioxidantes e marcadores de dano oxidativo em sangue humano: principais métodos analíticos para a sua determinação. Quim Nova. 2007, 30.

9. Chiu CJ, McArdle AH, Brown R, Scott HJ, Gurd FN. Intestinal mucosal lesion in low-flow states. A morphological, hemodynamic, and metabolic reappraisal. Arch Surg. 1970;101(4):478-83.

10. Guven A, Gundogdu G, Uysal B, Cermik H, Kul M, Demirbag S, Ozturk H, Oter S. Hyperbaric oxygen therapy reduces the severity of necrotizing enterocolitis in a neonatal rat model. J Pediatr Surg. 2009; 44:534-40

11. Flam F, Boijsen M, Lind F. Necrotizing fasciitis following transobturator tape treated by extensive surgery and hyperbaric oxygen. Int Urogynecol J Pelvic Floor Dysfunct. 2009;20:113-5.

12. Lee SW, Kim WJ, Jun HO, Choi YK, Kim KW. Angiopoietin-1 reduces vascular endothelial growth factor-induced brain endothelial permeability via upregulation of ZO-2. Int J Mol Med. 2009 23:27984.

13. Fan J, Cai H, Yang S, Yan L, Tan W. Comparison between the effects of normoxia and hypoxia on antioxidant enzymes and glutathione redox state in ex vivo culture of $\mathrm{CD} 34(+)$ cells. Comp Biochem Physiol B Biochem Mol Biol. 2008;151(2):153-8.

14. Thom SR, Bhopale VM, Velazquez OC, Goldstein LJ, Thom LH, Buerk DG. Stem cell mobilization by hyperbaric oxygen. Am J Physiol Heart Circ Physiol. 2006;290:1378-86.

15. Milovanova TN, Bhopale VM, Sorokina EM, Moore JS, Hunt TK, 
Hauer-Jensen M, Velazquez OC, Thom SR. Hyperbaric oxygen stimulates vasculogenic stem cell growth and differentiation in vivo. J Appl Physiol. 2009;106(2):711-28.

16. Kamota T, Li TS, Morikage N, Murakami M, Ohshima M, Kubo M, Kobayashi T, Mikamo A, Ikeda Y, Matsuzaki M, Hamano K. Ischemic pre-conditioning enhances the mobilization and recruitment of bone marrow stem cells to protect against ischemia/reperfusion injury in the late phase. J Am Coll Cardiol. 2009;53:1814-22.

17. Lin JS, Chen YS, Chiang HS, Ma MC. Hypoxic preconditioning protects rat hearts against ischaemia-reperfusion injury: role of erythropoietin on progenitor cell mobilization. J Physiol. 2008;586: 5757-69.

18. Li Z, Liu W, Kang Z, Lv S, Han C, Yun L, Sun X, Zhang JH. Mechanism of hyperbaric oxygen preconditioning in neonatal hypoxia-ischemia rat model. Brain Res. 2008;151-6.

19. Calvert JW, Zhou C, Nanda A, Zhang JH. Effect of hyperbaric on apoptosis in neonatal hypoxia- ischemia rat model.J Appl Physiol. 2003;95:1072-80.

20. Ostrowski RP, Graupner G, Titova E, Zhang J, Chiu J, Dach $\mathrm{N}$, Corleone D, Tang J, Zhang JH. The hyperbaric oxygen preconditioning-induced brain protection is mediated by a reduction of early apoptosis after transient global cerebral ischemia. Neurobiol Dis. 2008;29:1-13.

21. Bi W, Wang F, Bi Y, Wang T, Xue P, Zhang Y, Gao X, Liu S, Wang Z, Li M, Baudy-Floc'h M, Robinson SC, Ngerebara N, Bi L. Renal ischemia/reperfusion injury in rats is attenuated by a synthetic glycine derivative. Eur J Pharmacol. 2009;616:256-64

22. Li J, Liu W, Ding S, Xu W, Guan Y, Zhang JH, Sun X. Hyperbaric oxygen preconditioning induces tolerance against brain ischemiareperfusion injury by upregulation of antioxidant enzymes in rats. Brain Res. 2008;1210:223-9.

23. Bertoletto PR, Fagundes DJ, Simoes MJ, Oshima CT, Montero EFS, Simoes RS, Fagundes AT. Effects of hyperbaric oxygen therapy on the rat intestinal mucosa apoptosis caused by ischemia-reperfusion injury. Microsurgery. 2007;27:224-7.

24. Zhang Q, Chang Q, Cox RA, Gong X, Gould LJ. Hyperbaric oxygen attenuates apoptosis and decreases inflammation in an ischemic wound model. J Invest Dermatol. 2008;128:2102-12.

25. Wang L, Li W, Kang Z, Liu Y, Deng X, Tao H, Xu W, Li R, Sun $\mathrm{X}$, Zhang JH. Hyperbaric oxygen preconditioning attenuates early apoptosis after spinal cord ischemia in rats. J Neurotrauma. 2009;26:55-66.

26. Nylander G, Otamiri T, Lewis DH, Larsson J. Lipid peroxidation products in postischemic skeletal muscle and after treatment with hyperbaric oxygen. Scand J Plast Reconstr Surg Hand Surg. 1989;23:97-103

27. Han C, Lin L, Weidong Z, Zhang L, Lv S, Qiang, Tao H, Zhang JH, Sun X. Hyperbaric oxygen preconditioning alleviates myocardial ischemic injury in rats. Exp Biol Med. 2008;233:1448-53.

28. Efrati S, Gall N, Bergan J, Fishlev G, Bass A, Berman S, HamadAbu R, Feigenzon M, Weissgarten J. Hyperbaric oxygen, oxidative stress, NO bioavailability and ulcer oxygenation in diabetic patients. Undersea Hyperb Med. 2009;36:1-12.
29. Bosco G, Yang ZJ, Nandi J, Wang J, Chen C, Camporesi EM. Effects of hyperbaric oxygen on glucose, lactate, glycerol and antioxidant enzymes in the skeletal muscle of rats during ischemia and reperfusion. Clin Exp Pharmacol Physiol. 2007;34:70-6.

30. Kudchodkar B, Jones H, Simecka J, Dory L. Hyperbaric oxygen treatment attenuates the pro-inflammatory and immune responses in apolipoprotein E knockout mice. Clin Immunol. 2008;128:435-41.

31. Imperatore F, Cuzzocrea S, Luongo C, Liguori G, Scafuro A, De Angelis A, Rossi F, Caputi AP, Filippelli A. Hyperbaric oxygen therapy prevents vascular derangement during zymosaninduced multiple-organ-failure syndrome. Intensive Care Med. 2004;30(6):1175-81

32. Cuzzocrea S, Imperatore F, Costantino G, Luongo C, Mazzon E, Scafuro MA, Mangoni G, Caputi AP, Rossi F, Filippelli A. Role of hyperbaric oxygen exposure in reduction of lipid peroxidation and in multiple organ failure induced by zymosan administration in the rat. Shock. 2000;13:197-203.

\section{Correspondence:}

\section{Omar Feres}

Divisão de Coloproctologia - Departamento de Cirurgia e

Anatomia - HC-FMRP-USP

14048-900 Ribeirão Preto - SP Brasil

Tel./Fax: (55 16)3621-1122

omar.feres@hspaulo.com.br

rogeriosparra@gmail.com

Received: April 19, 2011

Review: June 15, 2011

Accepted: July 20, 2011

Conflict of interest: none

Financial source: none

1Research performed at Department of Surgery and Anatomy, Ribeirao Preto School of Medicine, University of Sao Paulo (FMRP-USP), Brazil.

Presented at the XII National Congress on Experimental Surgery of the Brazilian Society for the Development of Research in Surgery-SOBRADPEC 2011 October 26-29, Ribeirao Preto-SP, Brazil. 